Jurnal Ilmu Sosial dan Pendidikan (JISIP)

Vol. 6, No. 1 Januari 2022

e-ISSN : 2656-6753, p-ISSN: 2598-9944

DOI: 10.36312/ jisip.v6i1.2731/http://ejournal.mandalanursa.org/index.php/JISIP/index

\title{
Relevansi Undang-Undang Cipta Kerja (Omnibus Law) Terhadap Perlindungan Lingkungan Hidup Dalam Kerangka Gatt-Wto
}

\author{
Adi Kurniawan
}

Fakultas Hukum Universitas Indonesia

\begin{tabular}{l}
\hline \hline Article Info \\
\hline Article history: \\
Accepted: 07 Januari 2022 \\
Publish: 08 Januari 2022
\end{tabular}

Keywords:

Omnibus Law

Investasi

Lingkungan Hidup

\begin{tabular}{l}
\hline Article Info \\
\hline Article history: \\
Diterima: 07 Januari 2022 \\
Terbit: 08 Januari 2022
\end{tabular}

Corresponding Author:

Adi Kurniawan

Fakultas Hukum Universitas Indonesia

Email : adikurniawan900@gmail.com

\begin{abstract}
During the Jokowi-Ma'ruf administration, Indonesia was led towards investment politics. From a domestic perspective, Indonesia has successfully passed the Omnibus Law for job creation. With various offers of welfare through employment and investment opportunities, on the one hand the existence of the Job Creation Act has the potential to threaten the interests of the environment, not only for the existence of the community itself but also for the territory owned and the sources of livelihood in it. It is feared that the Omnibus Law will cut and change the concept of administrative requirements, this is related to business practices that will cause damage/change the function of space or the environment, including the centralization of policies, eliminating community involvement, flexibility and spatial adjustment, eliminating building permits, reduction of the substance of the AMDAL, and the abolition of environmental criminal sanctions. In addition, the Omnibus Law concept is intended to make it easier for investors to invest in Indonesia. However, environmental issues are not problems that stand alone, but are always related to various problems of life and even life between countries or issues of relations between countries which incidentally have a wedge with the agreement in the negotiations at the WTO in the context of environmental management and protection. This is the urgency for the Government's commitment to managing investments based on quality environmental sustainability.
\end{abstract}

\begin{tabular}{l}
\hline Abstract \\
\hline Pada masa pemerintahan Jokowi-Ma'ruf, Indonesia digiring ke arah politik investasi. \\
Dari segi domestik, Indonesia berhasil meloloskan Omnibus Law untuk penciptaan \\
lapangan kerja. Dengan berbagai tawaran kesejahteraan melalui lapangan kerja dan \\
peluang investasi, di satu sisi keberadaan dari Undang-undang Cipta Kerja tersebut \\
berpotensi mengancam kepentingan lingkungan, tidak hanya bagi eksistensi \\
masyarakat itu sendiri namun juga pada wilayah yang dimiliki serta sumber-sumber \\
penghidupan di dalamnya. Omnibus Law dikhawatirkan akan memangkas dan \\
mengubah konsep syarat- syarat administrasi, hal ini terkait dengan praktek usaha \\
yang akan menyebabkan kerusakan/mengubah fungsi ruang atau lingkungan antara \\
lain adanya sentralisasi kebijakan, menghilangkan pelibatan masyarakat, fleksibilitas \\
dan penyesuaian tata ruang, penghilangan izin mendirikan bangunan, reduksi atas \\
substansi AMDAL, dan penghapusan sanksi pidana lingkungan. Selain itu Konsep \\
Omnibus Law dimaksudkan untuk memudahkan investor untuk menanamkan modal \\
di Indonesia. Namun Persoalan lingkungan hidup bukanlah persoalan yang berdiri \\
sendiri, tetapi selalu terkait dengan berbagai persoalan kehidupan bahkan kehidupan \\
antar Negara atau persoalan hubungan antar Negara yang notabenenya memiliki irisan \\
dengan persetujuan dalam perundingan di WTO dalam konteks pengelolaan dan \\
perlindungan lingkungan hidup. Hal inlah yang menjadi urgensi perlu adanya \\
komitmen Pemerintah dalam mengelola investasi yang berdasar pada kelangsungan \\
lingkungan hidup yang berkualitas. \\
\hline This is an open access article under the Lisensi Creative Commons Atribusi- \\
BerbagiSerupa 4.0 Internasional \\
(i) (9)
\end{tabular}

\section{PENDAHULUAN}

Pada era periode pemerintahan Jokowi-Ma'ruf, Indonesia digiring ke arah politik investasi. Sejak terpilihnya Joko Widodo sebagai Presiden RI untuk kali kedua, pada pidato politik pertamanya, Jokowi dengan tegas dan gamblang meneriakkan keterbukaan terhadap investasi dengan dalih membuka lapangan kerja seluas-luasnya. Dari segi domestik, Indonesia berhasil 
meloloskan Omnibus Law untuk penciptaan lapangan kerja yang merupakan reformasi struktural terbesar sejak krisis 1997-1998. Undang-undang ini diharapkan dapat menyelesaikan hambatanhambatan investasi dasar seperti perizinan dan tenaga kerja. Pada dasarnya Omnibus Law Cipta Kerja bertujuan untuk menciptakan lapangan kerja dalam memenuhi hak konstitusional warga negara guna mendapatkan pekerjaan dan penghidupan yang layak. Rancangan Undang-undang Cipta Kerja disahkan pada 5 Oktober 2020 dan mencakup sepuluh bidang kebijakan yang terdiri dari: 1). Peningkatan ekosistem investasi dan kegiatan berusaha; 2). Ketenagakerjaan; 3). Kemudahan, perlindungan, serta pemberdayaan Koperasi dan UMKM; 4). Kemudahan berusaha; 5). Dukungan Riset dan inovasi; 6). Pengadaan lahan/tanah; 7). Kawasan ekonomi; 8). Investasi pemerintah Pusat dan Percepatan Proyek Strategi Nasional; 9). Pelaksanaan Administrasi Pemerintah untuk Mendukung Cipta Kerja; dan 10). Pengawasan dan Pembinaan.

Dengan adanya Undang-undang Cipta Kerja, upaya pemerintah untuk membuka pintu seluas-luasnya bagi investasi salah satunya dengan dibukanya Daftar Negatif Investasi (DNI) sebanyak 14 bidang usaha dari 20 DNI. Pemerintah juga menetapkan sebanyak 245 bidang usaha sebagai prioritas dalam mendorong investasi di dalam negeri. Sebanyak 245 bidang usaha prioritas tersebut tercantum dalam lampiran I Peraturan Presiden (Perpres) No. 10/2021 tentang Bidang Usaha Penanaman Modal, yang merupakan aturan turunan dari UU No. 11/2020 tentang Cipta Kerja. Berdasarkan Pasal 4 Perpres No. 10/2021, disebutkan bidang usaha prioritas mencakup bidang usaha yang merupakan program/proyek strategis nasional, padat modal, padat karya, teknologi tinggi, industri pionir, berorientasi ekspor, dan/atau berorientasi dalam kegiatan penelitian, pengembangan, dan inovasi.

Dengan berbagai tawaran kesejahteraan melalui lapangan kerja dan peluang investasi, di satu sisi keberadaan dari Undang-undang Cipta Kerja tersebut berpotensi mengancam kepentingan lingkungan, tidak hanya bagi eksistensi masyarakat itu sendiri namun juga pada wilayah yang dimiliki serta sumber-sumber penghidupan di dalamnya. Omnibus Law dikhawatirkan akan memangkas dan mengubah konsep syarat- syarat administrasi, hal ini terkait dengan praktek usaha yang akan menyebabkan kerusakan/mengubah fungsi ruang atau lingkungan, antara lain: adanya sentralisasi kebijakan, menghilangkan pelibatan masyarakat, fleksibilitas dan penyesuaian tata ruang, penghilangan izin mendirikan bangunan, reduksi atas substansi AMDAL, dan penghapusan sanksi pidana lingkungan. Diterimanya isu lingkungan hidup dalam Final Act of the Uruguay Round memang dapat dimengerti, karena dalam sejarahnya, GATT (Persetujuan Umum tentang Tarif dan Perdagangan) yang pertama kali disusun pada tahun 1947 telah secara eksplisit memberikan pengakuan akan perlunya perlindungan terhadap kesehatan manusia, binatang maupun tanam-tanaman.

\section{METODE PENELITIAN}

Untuk menyusun hasil penelitian tersebut, penulis melakukan studi kepustakaan dengan menggunakan metode penelitian Normatif yang pada dasarnya merupakan suatu kegiatan yang akan mengkaji aspek-aspek internal dari hukum positif. Metode penelitian hukum normatif menggunakan pendekatan yuridis normatif dimana Pendekatan yuridis normatif adalah pendekatan yang mengacu pada hukum dan Peraturan Perundang-Undangan yang berlaku.

\section{HASIL PENELITIAN DAN PEMBAHASAN}

\subsection{Omnibus Law dalam Perspektif Politik Hukum}

Pembentukan peraturan perundang-undangan dengan model omnibus law telah dimulai sejak masa penjajahan kolonial Belanda. Pada saat itu, pemerintah kolonial Belanda menyelesaikan konflik norma, utamanya yang menyangkut penduduk bumiputra dengan aturan yang dibuat pemerintah kolonial Belanda. Pada masa penjajahan Belanda, pola politik hukum yang dikembangkan adalah menempatkan norma hukum yang ada saat itu seperti hukum adat, hukum Islam di bawah kodifikasi hukum kolonial Belanda. Model omnibus law yang dibentuk pada saat masa kolonialisasi Belanda dalam arah politik hukum yaitu untuk menopang kegiatan perdagangan VOC, artinya pada fase tersebut dapat dipahami bahwa 
omnibus law senantiasa memiliki tema besar untuk kepentingan tertentu. Esensi omnibus law tidak berubah dari masa ke masa, yakni penyelesaian konflik norma dalam waktu cepat guna mencapai tujuan tertentu dengan membuat sebuah peraturan perundang-undangan yang memuat banyak substansi.

Salah satu hal yang mendorong untuk kembali dibentuknya perundangan berbasis omnibus law di tahun 2020 adalah guna mengantisipasi dampak tumpang tindih peraturan perundang-undangan dan tumpang tindih kewenangan sebagai dampak pelaksanaan otonomi daerah. Selain menyelesaikan konflik norma, omnibus law yang dibentuk di tahun 2020 juga memiliki tujuan untuk penataan kewenangan antar instansi. Salah satu dampak dari konflik norma adalah timbulnya gangguan pada fungsi birokrasi dalam melayani kepentingan publik, dalam hal ini adalah panjangnya birokrasi dalam memberikan pelayanan pada masyarakat. Debirokrasi menjadi arah politik hukum di tahun 2020 yang melatarbelakangi pembentukan omnibus law. Lahirnya Undang-undang Nomor 11 Tahun 2020 tentang Cipta Kerja adalah penyesuaian dengan arah politik hukum pada 2020 yang memprioritaskan pada penciptaan lapangan kerja maka diperlukan investasi, baik investasi dalam negeri maupun investasi yang bersumber dari penanaman modal asing (PMA).

Omnibus law tersebut merupakan format pembentukan undang-undang yang bersifat menyeluruh dengan turut mengatur materi undang-undang lain yang saling berkaitan dengan substansi yang diatur oleh undang-undang yang diubah atau dibentuk. Dengan format pembentukan omnibus law ini, pembentukan satu undang-undang dilakukan dengan mempertimbangkan semua materi ketentuan yang saling berkaitan langsung ataupun tidak langsung yang diatur dalam berbagai undang-undang lain secara sekaligus. Omnibus law dapat dianggap sebagai undang-undang 'Sapu Jagat' yang dapat digunakan untuk mengganti beberapa norma hukum dalam beberapa undang-undang.

Sesuai laporan kemudahan berusaha di Indonesia, peringkat kemudahan berusaha dan investasi di Indonesia pada tahun 2015 hingga 2020 terkendala oleh persoalan kepastian hukum. Sebagaimana laporan Bank Dunia bahwa rating Ease of Doing Business (EoDB) Indonesia mengalami penurunan karena disebabkan oleh empat faktor utama yakni terkait persoalan perizinan, perlindungan investor minoritas, kemudahan perdagangan lintas batas, dan terkait penegakan atas kontrak dagang. Keempat faktor yang menyebabkan turunnya rating EoDB Indonesia sebenarnya hanya bermuara pada satu hal yakni investor perlu iklim investasi yang mampu memberikan kepastian hukum bagi para investor. Persoalan ketidakpastian inilah yang kemudian berimbas pada investor yang hendak memulai usahanya di Indonesia. Upaya perbaikan yang harus dilakukan adalah melakukan debirokrasi aturan teknis sehingga mudah dan murah diakses serta membuat sistem yang transparan, memiliki standar, dan batas waktu pengurusan. Selain itu pemerintah perlu memperluas jangkauan OSS pada perizinan teknis. Kondisi tersebutlah yang mendorong lahirnya pembentukan peraturan perundang-undangan berbasis omnibus law, dalam hal ini yakni Undang-undang Nomor 11 Tahun 2020 tentang Cipta Kerja.

\subsection{Omnibus Law sebagai Pintu Perluasan Investasi}

Konsep Omnibus Law dikenal juga dengan omnibus bill yang sering digunakan di Negara yang menganut sistem common law seperti Amerika Serikat dalam membuat regulasi. Regulasi dalam konsep ini adalah membuat satu UU baru untuk mengamandemen beberapa UU sekaligus. Tumpang tindih regulasi akan berimplikasi pada iklim investasi di Indonesia, sebagai contoh ketika ada usulan memperbaiki regulasi di bidang kehutanan maka yang harus direvisi adalah UU No. 41/1999 tentang Kehutanan. Namun, masih ada ganjalan dalam peraturan lain, misalnya UU No. 32/2009 tentang Perlindungan dan Pengelolaan Lingkungan Hidup (PPLH) atau UU No. 5/1960 tentang Peraturan Dasar Pokok-Pokok Agraria. Konsep Omnibus Law dapat digunakan di Indonesia untuk penyeragaman kebijakan pusat dan daerah dalam menunjang iklim investasi, di mana konsep ini menjadi cara singkat sebagai solusi peraturan perundang-undangan yang saling berbenturan, baik secara vertikal maupun horizontal. Konsep Omnibus Law dimaksudkan untuk memudahkan investor untuk 
menanamkan modal di Indonesia. Sebagai catatan bahwa kemudahan berusaha di Indonesia atau Ease of Doing Business (EoDB) secara berangsur-angsur terus menunjukkan perbaikan signifikan, di mana pada tahun 2016 berada pada peringkat 106, saat ini sudah di peringkat 91. Omnibus Law secara teoritis dapat menjadi solusi atas konflik peraturan perundangundangan secara cepat, efektif, dan efisien. Namun demikian, perlu memperhatikan asas dalam peraturan perundang-undangan Indonesia yaitu asas lex posterior derogat legi priori (Undang-undang yang disahkan belakangan akan tetap bisa mengesampingkan omnibus law jika materi muatannya berbeda). Perlu harmonisasi secara hati-hati tidak hanya pada undangundang yang akan dicabut dengan omnibus law, namun demikian dengan Rancangan Undang Undang (RUU) lain yang sedang dibahas, sehingga Peraturan Pemerintah Pengganti UndangUndang (Perppu) bisa jadi opsi bentuk Omnibus Law.

Omnibus Law yang hadir sebagai konsep pembaharuan tatanan regulasi dengan tujuan meningkatkan investasi di Indonesia wajib dilaksanakan seluas-luasnya untuk kepentingan masyarakat sebagai mandat dari konstitusi UUD NRI 1945. Proses Omnibus Law harus memperhatikan aspek yuridis, politik, sosiologi, ekonomi serta aspek lingkungan. Dalam konteks yuridis, sistem perundang-undangan harus berimbang dalam aspek efektivitas dan akuntabilitas. Penanaman modal asing tampaknya selalu memberikan kesan akan membawa dampak modernisasi dan perubahan ekonomi suatu negara. Studi yang dilakukan oleh PBB telah menunjukkan bahwa modal asing belum tentu memberikan modal pada negara penerima, setidaknya seperti yang terjadi di Amerika Latin. Di sini, perusahaan penanaman modal asing tidak membawa modal ke negara penerima justru menggunakan modal yang ada di negara penerima. Dengan demikian, perusahaan modal asing yang diyakini akan memodernisasi dan mengubah struktur ekonomi karena merupakan sumber modal bagi negara berkembang belum tentu sepenuhnya benar.

Namun dengan adanya omnibus law melalui Undang-Undang Cipta Kerja, tentu hal tersebut dimaksudkan untuk mengubah struktur ekonomi menjadi lebih maju dengan menjadikan sumber daya manusia yang lebih produktif. Badan Pusat Statistik (BPS) melaporkan jumlah pengangguran periode Agustus 2020 mengalami peningkatan sebanyak 2,67 juta orang. Dengan demikian, jumlah angkatan kerja di Indonesia yang menganggur menjadi sebesar 9,77 juta orang. Omnibus law yang hadir dengan cita-cita perluasan investasi tentu diharapkan dapat menekan angka pengangguran pada isu ketenagakerjaan. Di sisi lain, akan menjadi hal yang ironis jika perluasan investasi tersebut membuka ruang untuk pengembangan sumber daya manusia namun di waktu yang bersamaan sumbu ledakan kerusakan terhadap lingkungan hidup juga dinyalakan. Pada tataran ideal, keinginan untuk membuka pintu investasi seluas-luasnya bagi para investor tidak mesti dikontradiksikan dengan kebutuhan manusia terhadap lingkungan hidup. Pada satu sisi, investasi merupakan salah satu variabel utama dalam peningkatan kualitas ekonomi dan menjadi kewajiban negara untuk menjaga iklim pergaulan internasional, karena di era globalisasi, suatu negara tidak akan mampu bergerak maju jika tidak melakukan hubungan kerja sama dengan negara lain untuk memenuhi kebutuhan dasar di negaranya. Pada sisi lain, apabila salah satu komponen ekosistem, misalnya kondisi hutan, mengalami perubahan maka sistem adaptasi dari organisme akan ikut berubah untuk menjaga keseimbangan alamiah.

\subsection{Omnibus Law Cipta Kerja dan Perlindungan Lingkungan Hidup dalam Kerangka GATT-WTO 1994}

Dalam Undang-Undang No. 11 Tahun 2020 tentang Cipta Kerja, yang dimaksud dengan lingkungan hidup adalah kesatuan ruang dengan semua benda, daya, keadaan, dan makhluk hidup, termasuk manusia dan perilakunya, yang mempengaruhi alam itu sendiri, kelangsungan perikehidupan, dan kesejahteraan manusia serta makhluk hidup lain. Pada Convention on Civil Liability for Damage Resulting from Activities Dangerous to the Environment Pasal 2 Ayat (1) mengartikan lingkungan sebagai: "The sum of all external conditions affecting the life, development and survival of an organism". Kedua definisi tersebut memberikan pengertian dan batasan di dalam ketentuan mengenai lingkungan 
bertujuan untuk memberikan perlindungan hukum sampai pada taraf sejauh mana konvensi internasional maupun ketentuan hukum nasional dapat mencakupnya, selain itu dapat pula menuntut tanggung jawab (responsibilty) maupun tanggung gugat (liabilty) bagi pelaku perusakan lingkungan.

Mengenai bentuk pertanggungjawaban tersebut, dalam omnibus law cipta kerja, Pada Bab III Bagian ketiga mengenai persetujuan lingkungan, yang mengubah ketentuan Pasal 82 UU Perlindungan dan Pengelolaan Lingkungan Hidup menjadi "Pemerintah Pusat berwenang untuk memaksa penanggung jawab usaha dan/atau kegiatan untuk melakukan pemulihan lingkungan hidup akibat pencemaran dan atau perusakan lingkungan hidup yang dilakukannya." Terlihat dalam perubahan tersebut hanya pada kewenangan pemerintah pusat yang mengambil alih kendali secara penuh, di mana sebelumnya Menteri, Gubernur atau Bupati/Walikota memiliki kewenangan untuk memaksa penanggung jawab usaha. Dari beberapa tuangan dalam omnibus law, terdapat beberapa Pasal yang menekankan pada aspek pemulihan lingkungan hidup. Di antaranya pada perubahan Pasal 55, Pasal 82, Pasal 82 B UU Lingkungan Hidup, Pasal 80 UU Kehutanan, Pasal 48 UU Panas Bumi.

Persoalan lingkungan hidup bukanlah persoalan yang berdiri sendiri, tetapi selalu terkait dengan berbagai persoalan kehidupan bahkan kehidupan antar Negara atau persoalan hubungan antar Negara. Di antaranya, aspek lingkungan hidup terlihat juga di dalam hubungan perdagangan internasional. Oleh karena itu ketentuan-ketentuan hukum perdagangan internasional sebagaimana GATT (General Agreement on Tariff and Trade) selalu memperhatikan aspek lingkungan dalam perdagangan internasional. Kesadaran masyarakat internasional atas setiap kegiatan yang dilakukan Negara kerap kali menyampingkan dampak lingkungan yang berdampak besar pada Negara berkembang dan miskin yang sebagian wilayahnya masih banyak SDA namun perlakukan eksploitasi ini sangat berdampak besar pada generasi yang akan datang. Pembangunan ekonomi yang dilakukan setiap Negara dalam perkembangannya, hanya memperhatikan kebutuhan umat manusia itu sendiri, manusia yang merupakan subjek utama pembangunan sedangkan sumber daya alam dan lingkungan serta ekosistemnya dijadikan objek pembangunan manusia. Alhasil, kerusakan dan pencemaran lingkungan terjadi hampir di belahan dunia.

Hukum lingkungan internasional klasik tumbuh dan berkembang melalui kebiasaan internasional yang aturan hukumnya tersebar di berbagai perjanjian-perjanjian bilateral. Disepakatinya Deklarasi Stockholm 1972 dianggap sebagai kerangka kebijakan hukum lingkungan internasional yang meletakkan pondasi dan dasar-dasar pengaturan pengelolaan lingkungan hidup. Dua puluh tahun kemudian konsep pengelolaan berwawasan lingkungan dipaduserasikan dengan kegiatan pembangunan yang prinsip-prinsip hukumnya menjadi dasar dan/atau tema daripada Deklarasi Rio de Jeneiro 1992. Disepakatinya dua Deklarasi Internasional tersebut membawa implikasi terhadap berbagai peraturan hukum, baik hukum nasional maupun hukum internasional, termasuk hukum perdagangan internasional yang diatur di dalam GATT/WTO sebagai norma hukum yang mengatur berbagai persoalan dan permasalahan di bidang perdagangan internasional sebagai salah satu komponen penting pembangunan nasional negara-negara anggota WTO.

Pemilik dan pengelola bisnis umumnya hanya mempertimbangkan operasi mereka dalam jangka pendek. Sebagian besar hanya 3 sampai 5 tahun mendatang, atau yang jarang sekali ada, sampai 10 tahun. Kondisi bisnis yang tidak diperkirakan (fase-fase siklus bisnis, kompetisi dari perusahaan lain, harga input yang diperlukan seperti bahan mentah, dan investor yang tak mau menunggu laba terlalu lama) mengharuskan mereka belaku demikian, juga permintaan spekulator untuk keuntungan jangka pendek. Berangkat dari hal tersebut, sering kali perusahaan/investor bertindak dengan cara-cara yang sama sekali mengabaikan batas alamiah dan kepentingan lingkungan hidup. Berdasar pada faktor tersebut, dalam melaksanakan proses investasi entah itu dari pihak investor maupun host country harus memperhatikan aspek lingkungan hidup. Selain kewajiban negara untuk melindungi Investor, Investor yang melakukan penanaman modal langsung juga memiliki kewajiban untuk 
mematuhi ketentuan hukum nasional, menghormati HAM, memperhatikan lingkungan hidup, dan melakukan uji tuntas (due diligence) sebelum berinvestasi untuk mengidentifikasi iklim berusaha negara tuan rumah. Dengan adanya tendensi dominan atas kewajiban negara tuan rumah melindungi investor asing di negaranya, hal tersebut bukan berarti investor tidak memiliki kewajiban secara internasional.

Proses perdagangan internasional tidak lepas dari proses investasi dan pendirian perusahaan di negara tempat basis produksi berada (host country). Mekanisme hukum internasional telah mengatur perdagangan dan kaitannya dengan cara-cara investasi (Trade Related Investment Measures (TRIMs)). TRIMs juga melarang tindakan investasi yang mengakibatkan terlanggarnya prinsip-prinsip perdagangan yang telah diatur oleh WTO. Ini menunjukkan bahwa dalam hubungan perdagangan internasional yang dilakukan antara korporasi transnasional dengan host country wajib saling menghargai dan dilarang saling mendiskriminasi, agar kemudian antara kedua belah pihak terwujud relasi perdagangan yang saling menguntungkan, tanpa melanggar prinsip-prinsip perdagangan internasional yang telah ditentukan oleh WTO/GATT. WTO 1994 mencantumkan secara eksplisit pengaturan mengenai lingkungan antara lain dengan dikeluarkannya "The Ministerial Decision on Trade and Environment" pada tanggal 15 April 1994. Dalam putusan tersebut bahwa WTO memiliki tiga prioritas program, yaitu kebijakan perdagangan dunia, kebijakan lingkungan dan pembangunan berkelanjutan. Selanjutnya, ketentuan yang mengatur tentang lingkungan hidup tersebar dalam beberapa kesepakatan WTO antara lain dalam Article XX huruf (b) dan (g) GATT. Article XX ini merupakan ketentuan utama yang mengatur isu lingkungan hidup. Dengan adanya Article $X X$ tersebut, maka negara penandatangan GATT diizinkan untuk memberikan perlakuan berbeda/diskriminatif kepada produk-produk atau tindakan investasi dari negara lain yang dinilai potensial untuk mengancam kesehatan dan keselamatan lingkungan hidupnya (penduduk, hewan dan tanaman).

\section{KESIMPULAN}

Terdapat 3 (tiga) kesimpulan yang diambil berdasarkan pembahasan secara keseluruhan. Pertama, dibentuknya perundangan berbasis omnibus law di tahun 2020 adalah guna mengantisipasi dampak tumpang tindih peraturan perundang-undangan dan tumpang tindih kewenangan sebagai dampak pelaksanaan otonomi daerah. Selain menyelesaikan konflik norma, omnibus law yang dibentuk di tahun 2020 juga memiliki tujuan untuk penataan kewenangan antar instansi. Salah satu dampak dari konflik norma adalah timbulnya gangguan pada fungsi birokrasi dalam melayani kepentingan publik, dalam hal ini adalah panjangnya birokrasi dalam memberikan pelayanan pada masyarakat. Debirokrasi menjadi arah politik hukum di tahun 2020 yang melatarbelakangi pembentukan omnibus law. Lahirnya Undang-undang Nomor 11 Tahun 2020 tentang Cipta Kerja adalah penyesuaian dengan arah politik hukum pada 2020 yang memprioritaskan pada penciptaan lapangan kerja maka diperlukan investasi, baik investasi dalam negeri maupun investasi yang bersumber dari penanaman modal asing (PMA).

Kedua, konsep Omnibus Law dimaksudkan untuk memudahkan investor untuk menanamkan modal di Indonesia. Omnibus Law yang hadir sebagai konsep pembaharuan tatanan regulasi dengan tujuan meningkatkan investasi di Indonesia wajib dilaksanakan seluas-luasnya untuk kepentingan masyarakat sebagai mandat dari konstitusi UUD NRI 1945. Proses Omnibus Law harus memperhatikan aspek yuridis, politik, sosiologi, ekonomi serta aspek lingkungan. Mekanisme hukum internasional telah mengatur perdagangan dan kaitannya dengan cara-cara investasi (Trade Related Investment Measures (TRIMs)). TRIMs juga melarang tindakan investasi yang mengakibatkan terlanggarnya prinsip-prinsip perdagangan yang telah diatur oleh WTO.

Ketiga, omnibus Law melalui Undang-Undang Cipta Kerja yang notabene merupakan upaya perluasan investasi dan peningkatan kualitas sumber daya manusia, memiliki irisan dengan persetujuan dalam perundingan di WTO dalam konteks pengelolaan dan perlindungan lingkungan hidup. GATT dalam Article XX memandatkan mengenai kebutuhan untuk melindungi manusia, 
hewan dan tumbuhan dalam proses perdagangan internasional atau tindakan investasi. Omnibus law sejatinya hadir untuk kelangsungan hidup jangka panjang sehingga mesti memperhatikan kualitas lingkungan alih-alih hanya fokus pada keuntungan dalam keterbukaan investasi.

\section{UCAPAN TERIMAKASIH}

Ucapan terima kasih kepada Universitas Indonesia yang telah memberikan kepercayaan kepada penulis untuk menyusun artikel ini sebagai suatu pembaharuan.

\section{DAFTAR PUSTAKA}

\section{Buku}

Benuf, Kornelius, dan Muhamad Azhar. Metodologi Penelitian Hukum sebagai Instrumen Mengurai Permasalahan Hukum Kontemporer. Gema Keadilan 7.1 2020: 20-33.

Christiawan, Rio. Omnibus Law: Teori dan Penerapannya. Jakarta: Sinar Grafika, 2021.

Husin, Sukanda. Hukum Lingkungan Internasional. Jakarta: Raja Grafindo Persada, 2016.

Magdoff, Fred dan John Bellamy Foster. Lingkungan Hidup dan Kapitalisme. Diterjemahkan oleh Pius Ginting. Tangerang Selatan: CV. Marjin Kiri, 2018.

\section{Jurnal}

Darmawan, Agus. Politik Hukum Omnibus Law dalam Konteks Pembangunan Ekonomi Indonesia. Indonesian Journal of Law and Policy Studies. Volume 1 No. 1. Mei 2020.

Gustira, Zevia dan Retno Kusniati. Pengaturan Aspek Lingkungan Hidup dalam Perdagangan Internasional Berdasarkan GATT/WTO. Uti Possidetis: Journal of International Law. Vol. 1 No. 2 (2020).

Kusumadara, Afifah. Perlindungan Lingkungan Hidup dalam Perdagangan Internasional. Jurnal Hukum dan Pembangunan. Vol. 25 No. 5. Juni 2017.

Prabowo, Adhi Setyo. et. al. Politik Hukum Omnibus Law di Indonesia. Jurnal Pamator. Volume 13 Nomor 1. April 2020.

Prakasa, Satria Unggul Wicaksana. Perdagangan Internasional dan HAM: Relasinya dengan Sustainable Development. Jurnal Hukum Novelty. Vol. 9 No. 1. Februari 2018.

Rahayu, Mella Ismelina Farma. Isu Penegakan Hukum Lingkungan Dalam Kerangka Perdagangan Bebas di Era Globalisasi. Mimbar: Jurnal Sosial dan Pembangunan. Vol. XIX No. 3. September 2003.

Sari, Ria Maya dan Muhammad Arman. Policy Paper: Mencermati Ancaman Perampasan wilayah Masyarakat Adat dalam UU No.3 Tahun 2020 tentang Perubahan atas UU No. 4 Tahun 2009 tentang Mineral dan Batu Bara dan UU No. 11 Tahun 2020 tentang Cipta Kerja.

Simatupang, Taufik H.. Kebijakan Pemerintah di Bidang Penanaman Modal Asing (PMA) dalam Rangka menimhkatkan Iklim Investasi di Indonesia. Lex Jurnalica, Volume 7 Nomor 3. Agustus 2010.

\section{Peraturan dan Konvensi}

Undang-Undang No. 11 Tahun 2020 tentang Cipta Kerja

General Agreement on Tariffs and Trade 1994

\section{Sumber Internet}

Alika, Rizky. UU Cipta Kerja Buka 14 Jenis Usaha yang Sebelumnya Tertutup bagi Asing. https://katadata.co.id/pingitaria/finansial/5f7ddb0c60090/uu-cipta-kerja-buka-14-jenisusaha-yang-sebelumnya-tertutup-bagi-asing. Diakses 20 Juni 2021.

Alim MA, Nur. Melihat Peluang Investasi di Indonesia. https://indonews.id/artikel/27492/Melihat-Peluang-Investasi-Di-Indonesia/. Diakses 19 Juni 2021.

Azzahra, Annisa. Memahami Kewajiban Negara Tuan Rumah dan Investor Asing dalam Investasi Langsung (Direct Investment).https://fh.unair.ac.id/memahami-kewajiban-negara-tuanrumah-dan-investor-asing-dalam-investasi-langsung-direct-investment/. Diakses pada 21 Juni 2021. 
Elena, Maria. Dukung Cipta Kerja 245 Bidang Usaha Disahkan Jadi Prioritas Investasi. https://ekonomi.bisnis.com/read/20210223/9/1359788/dukung-cipta-kerja-245-bidangusaha-disahkan-jadi-prioritas-investasi. Diakses 19 Juni 2021.

Fauzia, Mutia. Indonesia Resesi, Jumlah Pengangguran Naik Jadi 9,77 Juta Orang. https://money.kompas.com/read/2020/11/05/141654326/indonesia-resesi-jumlahpengangguran-naik-jadi-977-juta-orang. Diakses 20 Juni 2021. 